\title{
Effects of saline irrigation method on the growth of rice (Oryza sativa L.)
}

\author{
Adlian $^{1}$, Budiastuti Kurniasih², and Didik Indradewa ${ }^{2}$ \\ ${ }^{1}$ Faculty of Engineering and Agriculture, Nani Bili Nusantara University \\ Aimas, Sorong, West Papua 98414, Indonesia \\ 2Department of Agronomy, Faculty of Agriculture, Universitas Gadjah Mada \\ Jln. Flora no. 1, Bulaksumur, Sleman, Yogyakarta 55281, Indonesia \\ *Corresponding author: adlian@mail.ugm.ac.id
}

Received: 09 ${ }^{\text {th }}$ May 2017; Revised: 04 ${ }^{\text {th }}$ December 2019; Accepted: 06 ${ }^{\text {th }}$ January 2020

\section{Keywords:}

Irrigation water, rice

(Oryza sativa L.), salinity

\begin{abstract}
A field experiment was carried out to study rice growth under salinity stress in permanently flooded, intermittent, and saturated soil conditions. The experiment was conducted at field station of Faculty of Agriculture, Universitas Gadjah Mada located in Bantengan village, Banguntapan, Bantul, DIY, from August to November 2015. The treatments were arranged in a split-plot randomized complete block design, consisting of three irrigation methods as the main plot and two levels of salinity as the subplot, thereby resulting in six treatment combinations with three replications within each combination treatment. The three irrigation methods were permanent irrigation (flooded soil), intermittent irrigation (wet/dry soil), and irrigation above field capacity (saturated soil). The two levels of salinity were fresh water as control treatment (EC ${ }_{8}^{5} 0.3 \mathrm{dS} . \mathrm{m}^{-1}$ ) and saline water $\left(\mathrm{EC}_{8}^{5} 5 \mathrm{dS} . \mathrm{m}^{-1}\right)$. The results of the experiment showed that there was no significant interaction effect of irrigation method and salinity on all observed rice growth variables. Salt stress negatively affected the rice growth, including plant height, plant dry weight, leaf area, and leaf area ratio (LAR). Irrigation method significantly affected plant dry weight and number of tillers at 3 and 9 weeks after planting. Permanent irrigation resulted in the highest plant growth compared to intermittent irrigation and above field capacity condition.
\end{abstract}

\section{INTRODUCTION}

Rice (Oryza sativa L.) is the main staple food for Indonesian citizens. It plays a highly important role in the economic, social, and political aspects. There are approximately 18 million farmers cultivating rice as the main commodity. This phenomenon contributes as high as $66 \%$ to gross domestic product (GDP) of field crops. Additionally, rice production contributes to high job opportunity and income for more than 21 million householders, for $25 \%$ to $35 \%$ contribution (Department of Agriculture, 2008) . In 2015, the Statistical Bureau of Indonesia recorded that rice production was 75.55 million tons of dry milled rice (the highest value for a decade). Hence, rice is still considered a strategic commodity in economy and national food security so that the development of rice should be put on the top priority by the Indonesian government.

Earlier studies from Japan International Cooperation Agency (JICA) predicted that by 2020 , Indonesia will face deficiency in rice stock as much as $8,857,000$ tons. This great amount was calculated based on the national rice need and the condition of irrigation installation (Erdem, 2006). The statistical data reported by FAO (2005) indicated that up to $50 \%$ of irrigated land, particularly irrigated paddy field, crucially faced salinity problem. Every year, hundreds of thousands of irrigated land had been abandoned due to salinity problem (Abrol, 1986). This salinity problem is associated to water quality, and a long term of irrigation practice using saline water containing high concentration of salt would enormously generate 
salt accumulation in plant root zone and inhibit plant growth (Al-Zu'bi, 2007). Utama (2010) stated that low rainfall, high evaporation, and unmaintained water management are the most factors affecting the salinity problem in irrigated paddy field.

Irrigation is defined as an effort applied by farmers to supply water to the paddy field using regular irrigation system that positively supports the physiological process on the whole plant parts and makes nutrients in the root zone can be more easily absorbed by plant. Generally, farmers are accustomed to apply the continuous irrigation in their paddy field. Looking well-grown in waterlogged condition, rice plant condition, especially yield, would be actually negatively affected. According to Dat et al. (2006), permanent irrigation will deplete dissolved oxygen and carbon dioxide supply. As a consequence, plant growth will be morphologically and physiologically inhibited. Inefficient irrigation practice may occur through inappropriate irrigation method in terms of the quantity of water and timing aspect. Related to water management method, therefore, alternatives such as intermittent method and above field capacity condition are proposed to save water on irrigated paddy field.

Salinity stress in different irrigation will have different effects on rice growth. Continuously submerged saline irrigation is known to cause anaerobic soil conditions with high osmotic pressure. The study on the use of less water in intermittent irrigation and shredding on the saline land is still very limited, especially on its effect on the growth of rice plants. This study aimed to determine the effect of permanent irrigation (flooded soil), intermittent irrigation (wet/dry soil), and irrigation above field capacity (saturated soil) on the growth of rice plants.

\section{MATERIALS AND METHODS}

The experiment was conducted at field station of Faculty of Agriculture, Universitas Gadjah Mada located on Bantengan village, Banguntapan, Bantul, DIY, from August to November 2015.

Materials used were rice cv. 'Dendang', mixed fertilizers (formulated from SP-36, $\mathrm{KCl}$, and urea), cow manure, and technical salt. The soil used was Regosols. Field tools used were bucket, spade, cultivator, sickle, knife, measuring ruler, digital camera, and pen. Laboratory tools used were analytic scale, oven, leaf area meter, portable photosynthesis system LI-6400, leaf color chart, EC meter, microscope, $\mathrm{pH}$ meter, nail polish, transparent tape, preparation glass, beaker glass, reaction tube, measuring glass, and filter paper.

The treatments were arranged in a split-plot randomized complete block design with three irrigation methods designated as the main plot and two levels of salinity as the subplot, resulting in six treatment combinations with for replications within each combination. The three irrigation methods were permanent irrigation, intermittent irrigation, and irrigation above field capacity. Permanent irrigation was set with water head kept at a 5-cm high (flooded soil condition); intermittent irrigation was set with a 5-cm water head at every 5 days (wet/dry soil condition); and irrigation above field capacity

Table 1. Plant height and number of tillers at 3,6 , and 9 weeks after planting (WAP) under irrigation and salinity treatments

\begin{tabular}{lcccccc}
\hline \multirow{2}{*}{ Treatments } & \multicolumn{3}{c}{ Plant height $(\mathrm{cm})$} & \multicolumn{3}{c}{ Number of tillers } \\
\cline { 2 - 7 } & 3 WAP & 6 WAP & 9 WAP & 3 WAP & 6 WAP & 9 WAP \\
\hline Irrigation & $22.73 \mathrm{a}$ & $41.79 \mathrm{a}$ & $63.84 \mathrm{a}$ & $4.38 \mathrm{a}$ & $16.88 \mathrm{a}$ & $29.88 \mathrm{a}$ \\
\hline Permanent & $23.73 \mathrm{a}$ & $42.28 \mathrm{a}$ & $63.00 \mathrm{a}$ & $4.88 \mathrm{a}$ & $14.63 \mathrm{a}$ & $22.75 \mathrm{~b}$ \\
Intermittent & $24.25 \mathrm{a}$ & $41.38 \mathrm{a}$ & $61.55 \mathrm{a}$ & $3.75 \mathrm{~b}$ & $16.13 \mathrm{a}$ & $25.75 \mathrm{ab}$ \\
Above field capacity & \multicolumn{7}{c}{} & & & & \\
\hline Salinity & $20.33 \mathrm{~b}$ & $35.26 \mathrm{~b}$ & $53.17 \mathrm{~b}$ & $4.25 \mathrm{a}$ & $14.42 \mathrm{~b}$ & $25.00 \mathrm{~b}$ \\
\hline Saline & $26.81 \mathrm{a}$ & $48.37 \mathrm{a}$ & $72.43 \mathrm{a}$ & $4.42 \mathrm{a}$ & $17.33 \mathrm{a}$ & $27.25 \mathrm{a}$ \\
Control & $(-)$ & $(-)$ & $(-)$ & $(-)$ & $(-)$ & $(-)$ \\
\hline Interaction & 9.61 & 18.30 & 4.21 & 18.45 & 24.41 & 15.90 \\
\hline CV \% & &
\end{tabular}

Remark: Numbers followed by the same letters in one colomn indicate no significantly difference based on DMRT at $\alpha=5 \%$; (-) Indicate no interaction between factors. 
was set so that the field was kept at saturation, moist, and muddy (saturated soil condition) without water head. Meanwhile, two levels of salinity were fresh water as control treatment $\left(\mathrm{EC}_{8}^{5} 0.3 \mathrm{dS} . \mathrm{m}^{-1}\right)$ and saline water with $50 \mathrm{mM} \mathrm{NaCl}$ levels $\left(\mathrm{EC}_{8}^{5} 5 \mathrm{dS} . \mathrm{m}^{-1}\right)$. All treatments were applied two weeks after planting (2 WAP).

Observations were made on the plant height measured from the base of the stem to the highest leaf and the number of tillers made by counting the tillers that grew in each rice plant. Observation of plant height and number of tillers was performed at 3, 6 and 9 weeks after planting (WAP). The observations of plant dry weight, leaf area, and leaf area ratio (LAR) were carried out at 7 weeks after planting (WAP). The tools used in this observation were buckets, hoes, shovels, sickles, knives, gauges, digital cameras, and stationery, while the equipment for observation in the laboratory consisted of analytical scales, electric ovens, leaf area meters, Leaf Color Charts, EC meters, microscope, and $\mathrm{pH}$ meter. The observed values were analyzed statistically using analysis of variance (ANOVA) and Duncan's multiple range test (DMRT) was performed to compare means between treatments ( $\alpha=5 \%)$.

\section{RESULTS AND DISCUSSION}

\section{Plant height and number of tillers}

The plant growth is defined as an irreversible increase in size of cells and plant organs due to both cell division and enlargement. Plant height and number of tillers of rice are two common research variables of rice growth. Salisbury and Ross (1992) stated that measurement on plant height and number of tillers can be done in a nondestructive method. As shown in Table 1, there was no significant interaction effect of the irrigation methods and salinity treatments on plant height and number of tillers at 3,6, and 9 WAP. The irrigation methods did not significantly affect plant height at all three plant ages. Meanwhile, the salinity of $5 \mathrm{dS} \cdot \mathrm{m}^{-1}$ irrigation water significantly decreased plant height at all three plant ages as shown by the significantly shorter plant height compared to that of the untreated (control) plant.

Hardjowigeno et al. (2005) reported that rice is a well-adapted plant so that it can be grown in flooded (fully saturated soil) condition and less-wet field condition. Gribaldi et al. (2014) stated that the rice cultivated in flooding condition was suspected to have an adaptation ability by prolonging stem to hinder anaerobic condition (escape strategy). As a short-term (less than 10 days) response to flooding, rice adapted through submergence tolerance mechanism marked by limiting stem elongation (Manderscheid et al., 2012). This result is in accordance with the result of this study, showing that plant height in generative phase ( 3.6 and 9 WAP) was not significantly affected by irrigation method.

There were no significant differences in number of tillers between irrigation treatments as well as between salinity treatments at 6 WAP (Table 1). The rice plants treated with above-field capacity condition produced fewer number of tillers compared to those treated with permanent and intermittent irrigation at 3 WAP. However, The rice plants treated with intermittent irrigation produced fewer number of tillers than those treated with permanent irrigation at 9 WAP. The growing period of 3 WAP was the vegetative phase, in which the intermittent irrigation adequately supported the plant water requirement so that tiller formation actively occurred. At 9 WAP, when the plants entered generative phase, the plants required more water to elongate their stems. When the plants had stopped forming tillers, they started to performed stem elongation and spikelet formation. Inadequate water supply can limit the nutrient transportation and decrease photosynthetic activity as well. Consequently, permanent irrigation needs to be applied during generative growth phase. As in line with the previous study conducted by Jeki (2016), drying period for 5 days increased the number of tillers, which were then decreased it in specific period so that flooding was needed to be done. Donggulo (2017) mentions that the most supporting thickness of water layer on soil surface ranges from 5 to $7.5 \mathrm{~cm}$. If the head of water flooded on field is higher than the abovementioned range, the soil temperature will decrease. The decrease soil temperature will therefore constrain tiller formation.

The inhibited plant growth due to the salt stress is generally occurred. In this study, the height of plant experiencing salt stress significantly decreased compared to that of untreated (control) plant. High doses of salt solution can interfere with the plant growth. High $\mathrm{NaCl}$ content in the media causes decreased osmotic potential, thereby inhibiting water absorption by plants. The effect of $\mathrm{NaCl}$ treatment decreased the morphological parameters 
of plant height and number of tillers. This result is in line with the opinion of Yarsi et al. (2017), stating that the symptoms of salt poisoning in rice plants can be in the form of stunted growth, short plant height, low number of leaves, reduced tillers, whitish leaf tips, and chlorotic parts on the leaves. Furthermore, according to Utama (2010), the smaller the number of tillers formed the more sensitive the rice plants are.

\section{Plant dry weight, leaf area, and Leaf Area Ratio (LAR)}

There was no interaction effect of irrigation methods and salinity treatments on the plant dry weight, leaf area, and leaf area ratio (LAR) (Table 2). Irrigation methods only significantly affected plant dry weight, whilst salinity significantly affected plant dry weight, leaf area, and leaf area ratio. The plants treated with permanent irrigation had higher dry weight compared to those treated with other irrigation treatments. Meanwhile, those treated with above field capacity had the lowest dry weight. The dry weight, leaf area, and leaf area ratio (LAR) of plants experiencing salt stress were significantly lower than those of control plants.

The permanent irrigation increased the plant dry weight. It happened because the treatment produced higher number of tillers, thereby resulting in more biomass. The level of water irrigated, as high as 5 $\mathrm{cm}$, might be considered as suitable environment for plant growth, providing more water and nutrient compared to other irrigation treatments. The water availability in the root zone will significantly influence the plant growth and development. The plant growth can be measured from the dry weight. Plant dry weight is defined as total biomass, which is resulted from metabolism process in the whole parts of plant. According to Gardner et al. (1991), plant biomass is obtained from photosynthesis results and absorption of nutrient and water, where later on, $90 \%$ of photosynthesis result is expressed as dry weight (Dat et al., 2006).

A leaf is a main organ that plays role as a photosynthetic organ that produces assimilate. The ability of plant to perform photosynthesis is determined by leaf area (Gardner et al., 1991). The water availability is one of abiotic stresses that is able to decrease the plant growth and development. Statistically, all irrigation treatments did not affect leaf area and leaf area ratio (LAR). It is suspected that under all irrigation methods, there was still adequate water supply to support the photosynthesis and nutrient movement through cell wall and cell tissue so that as long as the cell remained turgid, the stability of leaf form and the process of stomatal opening and closing would perform. Leaf area and number of leaves become the determining factors of growth rate of plant, whereas leaf area ratio (LAR) expresses the total one-sided area of photosynthetic tissue per unit ground surface area, in which leaf enlargement is supported by assimilate translocation (Gardner et al., 1991).

In this study, the significant decrease in dry weight, leaf area, and leaf area ratio (LAR) was found in the plants expressing salt stress. The low

Table 2. Dry weight, leaf area, and Leaf Area Ratio (LAR) at 7 weeks after planting (WAP) under irrigation and salinity treatments

\begin{tabular}{|c|c|c|c|}
\hline Treatments & $\begin{array}{c}\text { Dry weight } \\
\text { (g) }\end{array}$ & $\begin{array}{l}\text { Leaf area } \\
\left(\mathrm{cm}^{2}\right)\end{array}$ & $\begin{array}{c}\text { LAR } \\
\left(\mathrm{dm}^{2} \cdot \mathrm{g}^{-1}\right)\end{array}$ \\
\hline \multicolumn{4}{|l|}{ Irrigation } \\
\hline Permanent & $27.02 \mathrm{a}$ & $718.13 \mathrm{a}$ & $372.57 \mathrm{a}$ \\
\hline Intermittent & $20.06 a b$ & $609.63 \mathrm{a}$ & $314.84 \mathrm{a}$ \\
\hline Above field capacity & $16.30 \mathrm{c}$ & $560.50 \mathrm{a}$ & $288.40 \mathrm{a}$ \\
\hline \multicolumn{4}{|l|}{ Salinity } \\
\hline Saline & $17.20 \mathrm{~b}$ & $536.42 \mathrm{~b}$ & $276.81 b$ \\
\hline Control & $25.05 \mathrm{a}$ & $722.42 \mathrm{a}$ & $373.73 \mathrm{a}$ \\
\hline Interaction & $(-)$ & $(-)$ & $(-)$ \\
\hline$\overline{\mathrm{CV} \%}$ & 22.41 & 13.93 & 13.72 \\
\hline
\end{tabular}


value of dry weight was suspected to be caused by the decrease in cell enlargement and division. As a result, the plant biomass was also reduced. According to Tavakkoli et al. (2011) , a higher increase in $\mathrm{NaCl}$ concentration leading to the absorption of $\mathrm{Na}^{+}$and $\mathrm{Cl}^{-}$in plant tissue will interfere plant metabolism. Salinity is negatively associated to leaf area. The higher the salinity concentration, the less the water loss through transpiration. Consequently, the decrease in leaf area is followed by the increase in respiration rate. Yuniati (2004) explained that leaf area expansion can be decreased by salinity stress because of the decrease in the cell turgor pressure. Furthermore, it will affect photosynthetic rate by decreasing the leaf quality and quantity. The reduced leaf area (LAR) illustrates that the salinity treatment allocates more photosynthate distribution to the growth of plant organs other than the leaves by accumulating it in the roots and stems of rice so that the total biomass produced increases. The decrease in photosynthesis is due to the high salt accumulation in mesophyll tissue and the increase in $\mathrm{CO}_{2}$ concentration within cell causing smaller stomatal opening. Shereen et al. (2005) found that an increase in salt concentration of the soil increased the osmotic pressure of the soil solution increased and inhibited water and nutrient uptake.

\section{CONCLUSIONS}

Salt stress at $5 \mathrm{dS} \cdot \mathrm{m}^{-1}$ negatively affected the rice growth, including plant height, plant dry weight, leaf area, and leaf area ratio (LAR). Irrigation methods affected number of tillers and plant dry weight. Permanent irrigation contributed to the highest plant growth compared to intermittent irrigation and above field capacity condition.

\section{ACKNOWLEDGMENTS}

We thank the flagship research for Faculty of Agriculture, Universitas Gadjah Mada for the financial support.

\section{REFERENCES}

Abrol, I. P. 1986. Salt-Affected Soils: Problems and prospects in developing countries. in: global aspects of food production. p.283-305. Research Report 11. Ed. M.S. Swaminathan; S.K. Sinha. Oxford: Tycooly International.

Al-Zu'bi, Y. 2007. Effect of irrigation water on agriculture soil in Jordan valley: An example from arid area conditions. J. Arid Environ., 70:63-79.

Dat, J. F., C. Parent, N. Capelli, A. Breger, and M. Crevecoeur. 2006. Sensing and signaling during plant flooding. J. Plant Physiology and Biochemistry., 42 : $273-282$.

Department of Agriculture. 2008. Panduan Pelaksanaan Sekolah Lapang Pengelolaan Tanaman Terpadu (SLPTT) Padi. Jakarta: Departemen Pertanian.

Donggulo, C.V. 2017. Pertumbuhan dan hasil tanaman padi (Oryza sativa L.) pada berbagai pola jajar legowo dan jarak tanam. J. Agroland., 24:27-35.

Erdem, T., Y. Erdem, H. Orta, and H.Okursoy. 2006. Water-yield relationships of potato under different irrigation methods and regimens. J. Science and Agriculture., 63:226-231.

FAO. 2005. Global network on integrated soil management for sustainable use of salt-affected soils.http://www.fao.org/tempref/agl/ agll/docs/misc23.pdf.

Gardner, F.P.; R.B. Pearce and R. L. Mitchell. 1991. Fisiologi tanaman budidaya. Terjemahan: Herawati Susilo. Jakarta: UI Press.

Gribaldi, R.A. Suwignyo, M. Hasmeda, and R. Hayati. 2014. Pengaruh pemupukan terhadap perubahan morfofisiologi dan varietas padi pada kondisi cekaman rendaman. J. Agron. Indonesia., 42:17-23.

Hardjowigeno, S.; H. Subagyo and R. M. Luthfi. 2005. Morfologi dan klasifikasi tanah sawah. in: Tanah sawah dan teknologi pengelolaannya. Bogor : Pusat Penelitian Tanah dan Agroklimat. Departemen Pertanian.

Jeki. 2016. Indeks sensitivitas stress beberapa varietas padi gogo pada cekaman kekeringan. J. Agrotekbis, . 4:369-373. 
Manderscheid, R., M. Erbs and H.J. Weige. 2012. Interactive effects of free-air $\mathrm{CO}_{2}$ enrichment and drought stress on maize growth. J. Eur Agron., 110:185-196.

Salisbury, F. B and C.W. Ross. 1992. Plant physiology, Hormones and plant regulators: auxins and gibberellins. J. American Plant Sci., 5:357-381.

Shereen, A., S. Mumtaz, S. Raza, M.A. Khan, and S. Solangi. 2005. Salinity effect on seedling growth and yield components of different inbred rice lines. J. Bot., 37:131-139.

Tavakkoli, E., F. Fatehi, S. Coventry, P. Rengasamy and G. K. McDonald. 2011. Additive effects of $\mathrm{Na}^{+}$ and $\mathrm{Cl}^{-}$ions on barley growth under salinity stress. J. Ex. Bot. 62:2189-2203.
Utama, M.Z.H. 2010. Effect of NaCl-stress on metabolism of $\mathrm{NO}^{3-}, \mathrm{NH}^{4+}$ and $\mathrm{NO}^{2-}$ at several rice varieties. J. Trop Soils., 15:189-194.

Yarsi, G., A. Sivaci, H.Y. Dasgan, O. Altuntas, R. Binzet and Y. Akhoundnejad. 2017. Effects of salinity stress on chlorophyll and carotenoid contents and stomata size of grafted and ungrafted Galia C8 melon cultivar. J. Bot., 49: 421-426.

Yuniati, R. 2004. Penapisan galur kedelai Glycine max (L.) Merrill toleran terhadap $\mathrm{NaCl}$ untuk penanaman di lahan salin. J. Makara. Sci., $8: 21-24$ 